\title{
Glacier change over the past four decades in the middle Chinese Tien Shan
}

\author{
Baolin LI, ${ }^{1}$ A-Xing ZHU, ${ }^{1,2}$ Yichi ZHANG, ${ }^{1}$ Tao PEI, ${ }^{1}$ Chengzhi QIN, ${ }^{1}$ Chenghu ZHOU ${ }^{1}$ \\ ${ }^{1}$ State Key Laboratory of Resources and Environmental Information System, Institute of Geographical Sciences and \\ Natural Resources Research, Chinese Academy of Sciences, 11 Datun Road, An Wai, Beijing 100101, China \\ E-mail: libl@Ireis.ac.cn \\ ${ }^{2}$ Department of Geography, University of Wisconsin-Madison, 550 North Park Street, Madison, Wisconsin 53706-1491, USA
}

\begin{abstract}
Terminus fluctuation and area change in mountain glaciers in the middle Chinese Tien Shan over the past four decades are examined, based on Landsat multispectral scanner (MSS), Enhanced Thematic Mapper Plus (ETM+), Système Probatoire pour l'Observation de la Terre (SPOT) highresolution visible (HRV) imagery, topographical maps and China Glacier Inventory data using Geographical Information System (GIS) and remote-sensing techniques. This study shows that the glaciers in the study area have undergone continuous recession between 1963 and 2000 . Over the past 37 years the total glacier area decreased from $55 \times 10^{6} \mathrm{~m}^{2}$ to $48 \times 10^{6} \mathrm{~m}^{2}$ (a 13\% decrease). The glaciers at low elevations decreased more rapidly than those at high elevations. Seven of the ten large valley glaciers in the study area retreated by at least $150 \pm 49 \mathrm{~m}$ during this period. The average rate of recession for these glaciers was 4-8 $\mathrm{m} \mathrm{a}^{-1}$. The recession rate between 1986 and 2000 was larger than between 1963 and 1986 . The glacier changes in the study area were similar to those in the Ürümqi river basin in the northern Chinese Tien Shan. It is apparent that temperature rise over the past four decades has had a profound impact on these glaciers.
\end{abstract}

\section{INTRODUCTION}

Among the temperate countries at low latitudes, China has the most abundant mountain glacier resources, with 46298 glaciers covering a total volume of $5590 \mathrm{~km}^{3}$ (Shi and others, 2000). However, research work on mountain glacier change has been limited in China, compared with Europe where extensive studies on glacier changes have been conducted over a long period of time (e.g. Haeberli and others, 2005; Kjøllmoen, 2005). The first glacier-monitoring station in China was established in the source region of the Ürümqi river basin in 1959. Further research began in the 1960s, and the China Glacier Inventory was completed in 1999. Glacier change detection studies have been conducted only at a limited number of locations and over a short period of time (between the 1960s and the 1980s). Since the 1990s, remote-sensing data and techniques have played an increasing role in detecting glacier change (e.g. Liu and others, 2003). The majority of research on mountain glacier changes in China has focused on the mountains of the Tibetan Plateau (e.g. Fujita, 2000; Liu and others, 2003; Yang and others, 2003; Jin and others, 2005).

Research on changes in mountain glaciers in the Chinese Tien Shan is very limited, despite the fact that the number of glaciers in this region is the largest among all the mountain ranges in China, and the glaciers in this region provide very important water resources for local economic development. There has been some research work in the Chinese Tien Shan. It has focused on glaciers in the Ürümqi river basin on the northern side of the range, but, even there, change detection is limited to Ürümqi glacier No. 1 (UG1; e.g. Cao, 1998; Wang and others, 2004) and it is necessary to document glacier change in other parts of the Chinese Tien Shan. This paper examines mountain glacier changes in the middle Chinese Tien Shan over 37 years. Changes in termini and in areal extent are used as indices to measure glacier changes. Landsat multispectral scanner (MSS), Enhanced
Thematic Mapper Plus (ETM+), Système Probatoire pour I'Observation de la Terre (SPOT) high-resolution visible (HRV) imagery, topographical maps and the China Glacier Inventory data are used to detect these changes.

\section{METHODOLOGY}

\section{Study area}

The study area is centered at about $42^{\circ} 33^{\prime} 58^{\prime \prime} \mathrm{N}, 85^{\circ} 28^{\prime} 35^{\prime \prime} \mathrm{E}$ in Hejing County, Xinjiang Uygur Autonomous Region, China. It is located in the Albin mountains, a sub-range of the Chinese Tien Shan to the east of the Kaidu river (Fig. 1). The study area has the highest glacier density in the Chinese Tien Shan, i.e. more than 150 glaciers per $1000 \mathrm{~km}^{2}$. The elevation of the study area ranges from 3000 to $5000 \mathrm{~m}$ and the firn line is normally observed at about $4000 \mathrm{~m}$ in late summer. The Chinese Tien Shan can be divided into three parts (Fig. 2): northern, middle and southern. Our study area is located in the middle Chinese Tien Shan.

Glacial runoff in the study area provides one of the main sources of water for the oases at the foothills of the Chinese Tien Shan. The oases in these areas have become some of the most developed regions in the arid zone of China and are regarded as some of the most successful development areas in the Xinjiang Uygur Autonomous Region. Glacial runoff is one of the major water supplies to a population of more than 15 million (up to 1998) and determines oasis sustainability in the area.

\section{Data sources}

Three sets of remotely sensed images including Landsat MSS, SPOT HRV and Landsat ETM+ were acquired (Table 1). The SPOT HRV data were orthorectified using 18 ground-control points (GCPs) with rms errors of $<0.5$ pixels in both the $x$ and $y$ directions. The other two images were then geometrically orthorectified using image-to-image registration 


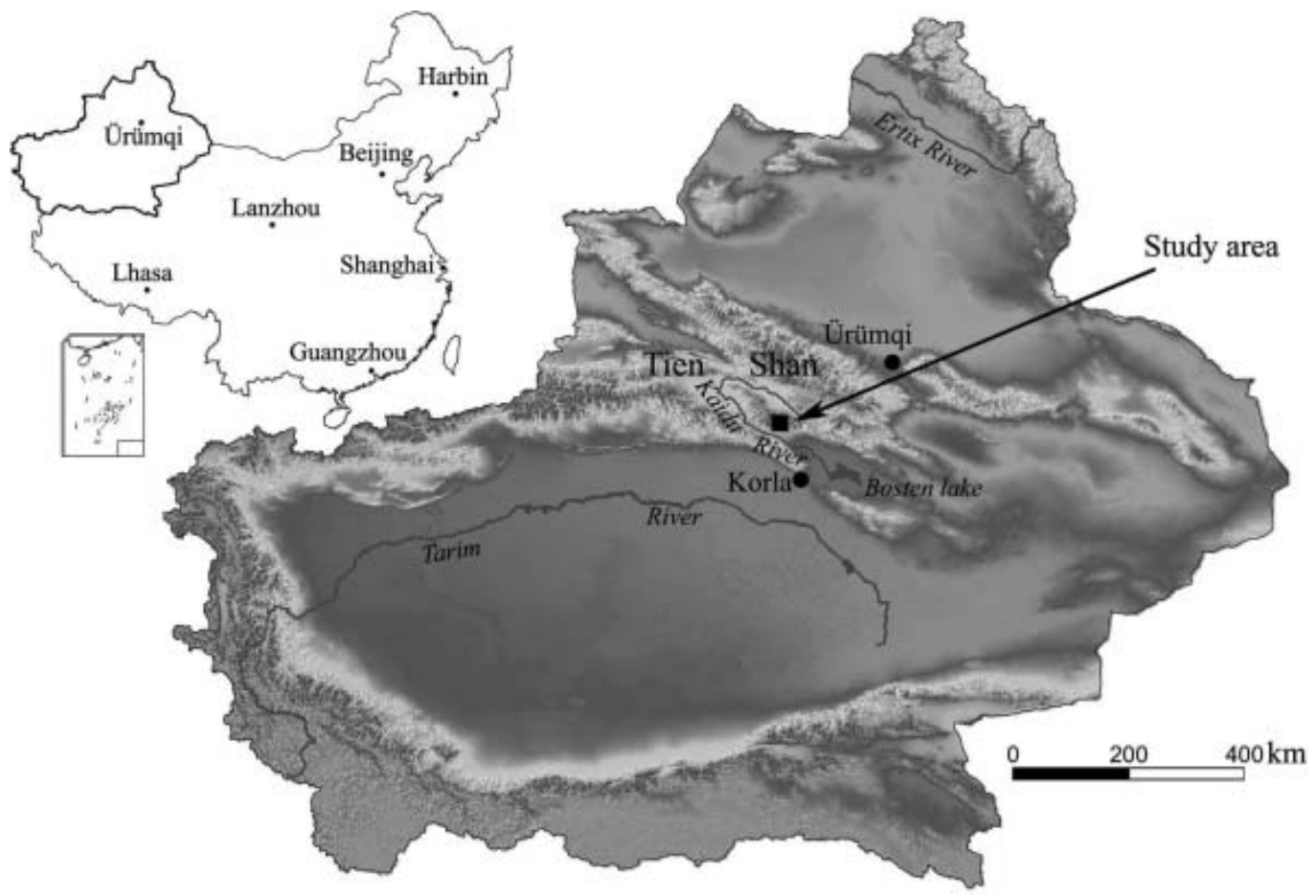

Fig. 1. Location of the study area.

with SPOT HRV image as the master. The registration errors were $<0.5$ pixels in both the $x$ and $y$ directions (Table 1 ). Two topographical maps at a scale of $1: 100000$ based on aerial photos taken in 1963 were also used. The topographical maps were scanned and registered with rms errors of $2.9 \mathrm{~m}$ in the $x$ direction and $2.7 \mathrm{~m}$ in the $y$ direction, based on the coordinates and projection information on the maps.

The glacier statistics in the China Glacier Inventory were used to obtain the areas of glaciers (LIGG, 1987). There are a total of 70 glaciers in the study area (Fig. 3). The glacier measurements from the China Glacier Inventory in the study area are based on aerial photos taken in 1963. Thus, glacier size information should be considered as it was in 1963 .

\section{Indices and data selection}

The terminus position of large glaciers and the areal extent of glaciers can be easily measured using optical remotesensing data, and these measures are used as indices for detecting mountain glacier changes. It is difficult to determine the connected boundaries of glaciers using remotesensing data (Paul, 2002), so areas of individual glaciers are

Table 1. Data used in this research, and the rms errors on geometric correction and registration of these images

\begin{tabular}{|c|c|c|c|c|c|c|c|}
\hline \multirow[t]{2}{*}{ Satellite } & \multirow[t]{2}{*}{ Sensor } & \multirow[t]{2}{*}{ r Path/row } & \multirow[t]{2}{*}{ Resolution } & \multirow{2}{*}{$\begin{array}{l}\text { Acquisition } \\
\text { date }\end{array}$} & \multicolumn{3}{|c|}{ Errors } \\
\hline & & & & & $\begin{array}{l}x \\
\mathrm{~m}\end{array}$ & $\begin{array}{l}y \\
\mathrm{~m}\end{array}$ & $\begin{array}{c}\text { Total } \\
\mathrm{m}\end{array}$ \\
\hline Landsat 2 & MSS & $155 / 30$ & $57^{*}$ & 15 Aug. 1977 & 36.2 & 17.3 & 40.1 \\
\hline SPOT 1 & HRV & $215 / 264 / 4$ & 20 & 30 Aug. 1986 & 10.3 & 10.7 & 14.9 \\
\hline Landsat 7 & ETM+ & $144 / 30$ & 30 & 7 Aug. 2000 & 8.4 & 15.6 & 17.7 \\
\hline
\end{tabular}

* Resampled data were provided by the National Center for Earth Resources Observation and Science (EROS), US Geological Survey (USGS). difficult to measure accurately. Therefore the total area of all glaciers in the study area is specified as an index for detecting the areal change of mountain glaciers.

For terminus change detection over the past 37 years, the topographical maps and three sets of remote-sensing data were used. The terminus positions in 1963 were derived from topographical maps because there is no detailed location information on glacier termini in the China Glacier Inventory.

Among the 70 glaciers, some small glaciers have disappeared and some are covered by seasonal snowpack or clouds during some periods. Thus, it is impossible to detect the terminus changes of all 70 glaciers; only some large valley glaciers, which present clear terminus changes, were selected for this purpose. The selection of glaciers for the terminus change study was based on two criteria: (1) relatively large glaciers with clear termini, and (2) an

Table 2. Glaciers used for detecting terminus changes

\begin{tabular}{rlccl}
\hline Glacier ID Inventory ID & Area & $\begin{array}{c}\text { Terminus } \\
\text { elevation } \\
\text { in } 1963\end{array}$ & $\begin{array}{l}\text { Orientation (aspect) } \\
\text { of accumulation } \\
\text { zones }\end{array}$ \\
& & & & \\
& & $10^{6} \mathrm{~m}^{2}$ & $\mathrm{~m}$ & \\
\hline & & & & \\
1 & $5 Y 695 \mathrm{~B}-6$ & 2.01 & 3730 & Northwest \\
2 & $5 Y 695 \mathrm{~B}-15$ & 8.51 & 3662 & North \\
3 & $5 Y 695 \mathrm{~B}-26$ & 1.47 & 3820 & Northwest \\
4 & $5 Y 695 \mathrm{~B}-28$ & 0.89 & 3840 & Northwest \\
5 & $5 Y 696 \mathrm{G}-78$ & 1.83 & 4025 & South \\
6 & $5 Y 696 \mathrm{G}-81$ & 2.29 & 4010 & Southwest \\
7 & $5 Y 696 \mathrm{H}-9$ & 0.55 & 3770 & North \\
8 & $5 Y 696 \mathrm{H}-11$ & 1.22 & 3740 & North \\
9 & $5 Y 696 \mathrm{H}-12$ & 2.30 & 3795 & Northeast \\
10 & $5 Y 696 \mathrm{H}-14$ & 0.88 & 3870 & North \\
\hline
\end{tabular}




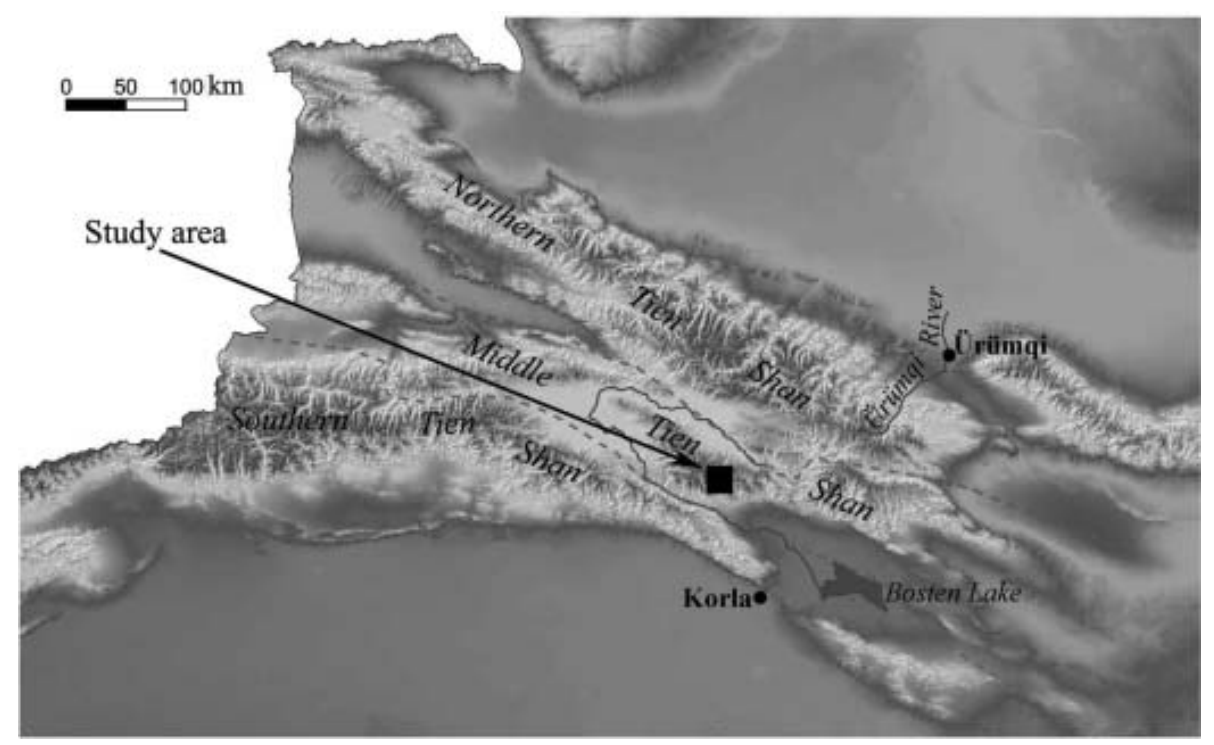

Fig. 2. Sub-areas of the Chinese Tien Shan.

even distribution of glaciers over the study area. Using these criteria, 10 of the 70 glaciers were selected for studying terminus changes (Fig. 3). The terminus elevations and aspects of these 10 glaciers are listed in Table 2 and these glaciers cover a wide range of environmental conditions. We believe these terminus changes are representative of those in the area.

For areal change detection, only the data based on the China Glacier Inventory and 2000 Landsat ETM+ were used. The areal extents in 1977 and 1986 cannot be estimated from the images between 1977 and 1986 because some areas were covered by clouds or fresh snow, precipitated just prior to the acquisition dates of the images.

\section{Glacier terminus change}

\section{Interval selection}

Five intervals were selected, based on data availability, for performing terminus change detection. These intervals were 1963-77, 1963-986, 1963-2000, 1977-86 and 1986-2000 using topographical maps, the 1977 Landsat MSS data, the 1986 SPOT HRV data and the 2000 Landsat ETM+ data.

\section{Terminus change and change rate}

Locations of glacier termini for 1963 were found using topographical maps, and those for 1977, 1986 and 2000 were determined through visual interpretation of false-color composites of the remotely sensed images. The specific process for locating the positions of termini is as follows (Fig. 4). First, the outlines of the glacier tongues of the ten glaciers for every dataset are digitized. Then, the glacier tongue tips are determined (symbols) through visual interpretation. Finally, the distances between individual glacier tongue tips are measured as terminus change distances (the distances between two symbols). The average rate of terminus change is computed by dividing the distance by the corresponding time interval.

\section{Uncertainty assessment}

Discussion of the terminus changes should be considered in the context of the associated uncertainty. Hall and others (2003) and Silverio and Jaquet (2005) partitioned the uncertainty in terminus changes into two categories: uncertainty related to the spatial resolution of the dataset and uncertainty due to errors in imagery registration. The spatial-resolution-related uncertainty, $U_{\text {res, }}$ is estimated from (Hall and others, 2003; Silverio and Jaquet, 2005):

$$
U_{\text {res }}=\sqrt{r_{\mathrm{a}}^{2}+r_{\mathrm{b}}^{2}}
$$

where $r_{\mathrm{a}}$ and $r_{\mathrm{b}}$ are the resolutions of images $\mathrm{a}$ and $\mathrm{b}$, respectively. The uncertainty associated with registration error of the images is approximated by the error of image registration directly. The total uncertainty associated with terminus change is then the sum of these two parts.

In this study, there are two differences in the way the uncertainty associated with glacier terminus change is measured, compared with that proposed by Hall and others

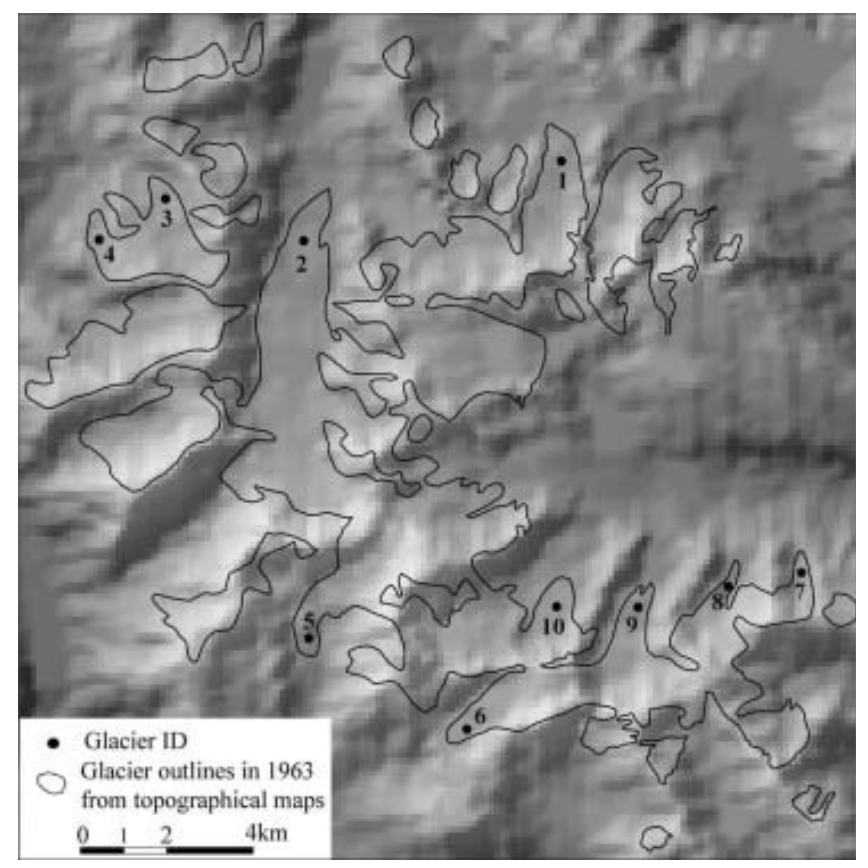

Fig. 3. The glacier distribution and glaciers used for detecting the change of termini. 

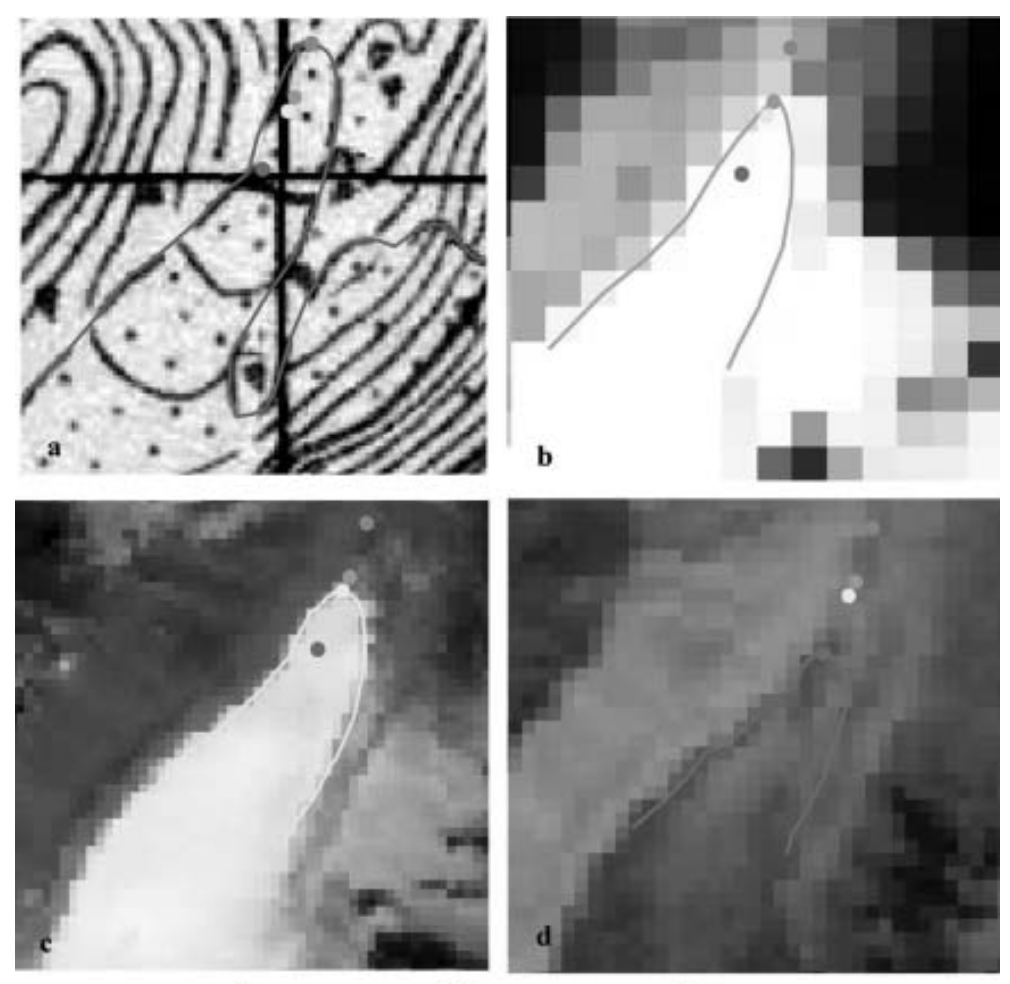

0

0.5

$1 \mathrm{~km}$

Fig. 4. Measuring glacier terminus change using topographical map and remote-sensing images. (a) Topographical map; (b) Landsat MSS; (c) SPOT HRV; and (d) Landsat ETM+.

(2003) and Silverio and Jaquet (2005). One is that not all the data are images (the 1963 data are from topographical maps). For the topographical maps, we used the mapping accuracy instead of the imagery resolution to measure the uncertainty related to sensor resolution. The topographical map accuracy, at a scale of $1: 100000$ over mountains, is $<7.5 \mathrm{~m}$ in the horizontal.

The other difference is that the master image is also orthorectified in this study. The master image contains strong distortions caused by topographical relief due to the high mountains in the area. These distortions need to be corrected so that serious location errors can be avoided when determining terminus positions. Since the master image is registered, all the images and maps have their own registration errors. Thus, the registration errors associated with the terminus change between two dates should be determined based on the registration errors for images on

Table 3. Errors ( $\mathrm{m}$ ) measuring glacier termini using registered maps or satellite images

Uncertainty $\quad 1963-77 \quad 1963-86 \quad 1963-2000 \quad 1977-86 \quad 1986-2000$ type

\begin{tabular}{lrrrrr}
\hline Registration & 40.3 & 15.4 & 18.1 & 42.8 & 23.1 \\
Resolution & $79.4^{*}$ & 21.4 & 30.9 & $81.5^{*}$ & 36.1 \\
Total & 119.7 & 36.8 & 49.1 & 124.3 & 59.2 \\
\hline
\end{tabular}

*The real resolution, $79 \mathrm{~m}$, of Landsat MSS (not the resampled resolution, $57 \mathrm{~m}$ ) was used to compute the resolution uncertainty. those dates, using a formula similar to that of Equation (1) for uncertainty related to sensor resolution.

\section{Glacier area change}

There are a number of methods for determining the areal extent of glaciers using Landsat ETM+ data. Band ratio thresholding using TM4/TM5, normalized-difference snow index (NDSI) and supervised classification are most commonly used (e.g. Sidjak and Wheate, 1999; Paul, 2002). Sidjak and Wheate (1999) have shown that supervised classification such as maximum likelihood classification (MLC) is most useful where there are many lakes at the margins of glaciers. This is the situation in our study area, and MLC is used to map the glacier areal extent using Landsat ETM+ data.

Kappa statistics and overall accuracy were computed to evaluate glacier-mapping accuracy (Congalton and Green, 1999). Five hundred sample points, based on a stratified random sampling scheme, were selected for 'ground truth'. The determination of ground truth for these samples was based on visual interpretation of Landsat ETM+ images. These ground-truth data were then used to compute the accuracy statistics.

The overall accuracy is $96.1 \%$ and the kappa statistic is 0.90 for the glacier map based on 2000 Landsat ETM+. This shows that the accuracy of the glacier map is quite high and, thus can be used to determine the areal change of glaciers in the study area.

The glacier information statistics in the China Glacier Inventory do not report the areal accuracy of glaciers in the study area. However, the glacier measurements were conducted according to the World Glacier Inventory (WGI) 

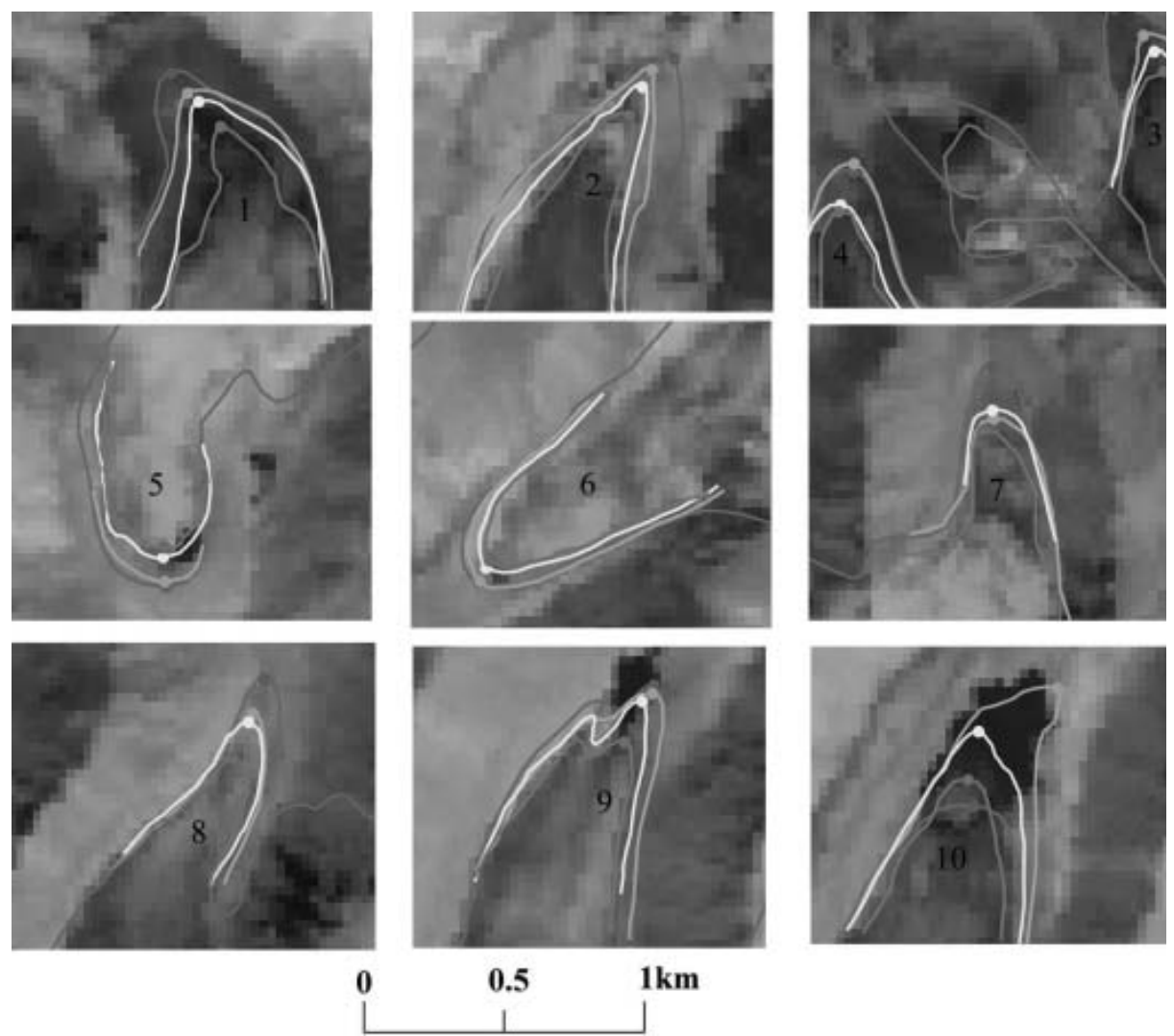

Fig. 5. Glacier terminus fluctuation over 37 years. Glacier ID, from 1 to 10 , is labeled on each glacier.

criteria of the World Data Center (WDC) and were checked by the World Glacier Monitoring Service (WGMS) when they were loaded into the WGI database in Zürich (http:// nsidc.org/data/docs/noaa/g01130_glacier_inventory/). We believe the accuracy of the area information to be acceptable.

\section{RESULTS}

\section{Glacier terminus change}

Tables 3 and 4 list glacier terminus changes and associated uncertainties over the study periods. The total uncertainties between 1963 and 1977 and between 1977 and 1986 were $119.7 \mathrm{~m}$ and $124.3 \mathrm{~m}$, respectively. The terminus changes of five glaciers between 1963 and 1977, and eight glaciers between 1977 and 1986 were less than the associated uncertainties. Thus, most glacier terminus changes over these two periods cannot be clearly identified.

The terminus changes for all ten glaciers between 1963 and 2000 are greater than the corresponding total uncertainties. The terminus changes for all ten glaciers between 1963 and 1986 exceeded the associated uncertainties. The terminus changes for seven of the ten glaciers between 1986 and 2000 exceeded the associated uncertainties. Thus, most glacier terminus changes over these three periods can be positively identified (Tables 3 and 4).

Seven glaciers retreated by at least $150 \pm 49 \mathrm{~m}$ between 1963 and 2000. All glaciers studied, except for glaciers 5, 6 and 10 (Fig. 3), exhibited average terminus recession rates of $4-8 \mathrm{~m} \mathrm{a}^{-1}$. The glacier terminus recession rate between 1986 and 2000 was, in general, larger than that between 1963 and 1986. For most glaciers, the recession rate between 1963 and 1986 was $4-7 \mathrm{~m} \mathrm{a}^{-1}$ and between 1986 and 2000 was $5-12 \mathrm{~m} \mathrm{a}^{-1}$. Among these glaciers, the recession rates of glaciers 1, 2, 8 and 9 between 1986 and 2000 were obviously faster than between 1963 and 1986 . Glacier 10 advanced $11.5 \mathrm{~m} \mathrm{a}^{-1}$ between 1963 and 1986 and retreated $12.6 \mathrm{~m} \mathrm{a}^{-1}$ between 1986 and 2000 (Table 4; Fig. 5).

\section{Glacier area change}

The total area of the 70 glaciers in the study area of the middle Chinese Tien Shan decreased by $13 \%$ (from $55 \times 10^{6} \mathrm{~m}^{2}$ to $48 \times 10^{6} \mathrm{~m}^{2}$ ) between 1963 and 2000 . It is no surprise that glaciers at lower elevations decreased more quickly than those at higher elevations (Fig. 6). For example,

Table 4. Glacial terminus changes over the past 37 years

\begin{tabular}{rrrrrrrr}
\hline & \multicolumn{2}{c}{$1963-86$} & \multicolumn{2}{c}{$1986-2000$} & \multicolumn{2}{c}{$1963-2000$} \\
Glacier ID & Distance & Rate & Distance & Rate & Distance & Rate \\
& $\mathrm{m}$ & $\mathrm{m} \mathrm{a}^{-1}$ & $\mathrm{~m}$ & $\mathrm{~m} \mathrm{a}^{-1}$ & $\mathrm{~m}$ & $\mathrm{~m} \mathrm{a}^{-1}$ \\
& & & & & & \\
\hline 1 & -150 & -6.5 & -120 & -8.6 & -276 & -7.5 \\
2 & -146 & -6.3 & -113 & -8.1 & -264 & -7.1 \\
3 & -219 & -9.5 & -83 & -5.9 & -286 & -7.7 \\
4 & -124 & -5.4 & -28 & -2.0 & -158 & -4.3 \\
5 & -105 & -4.6 & -41 & -2.9 & -134 & -3.6 \\
6 & -59 & -2.6 & -29 & -2.1 & -89 & -2.4 \\
7 & -162 & -7.0 & -78 & -5.6 & -239 & -6.5 \\
8 & -161 & -7.0 & -143 & -10.2 & -307 & -8.3 \\
9 & -79 & -3.4 & -159 & -11.4 & -229 & -6.2 \\
10 & +264 & +11.5 & -176 & -12.6 & +85 & +2.3 \\
& & & & & & \\
\hline
\end{tabular}




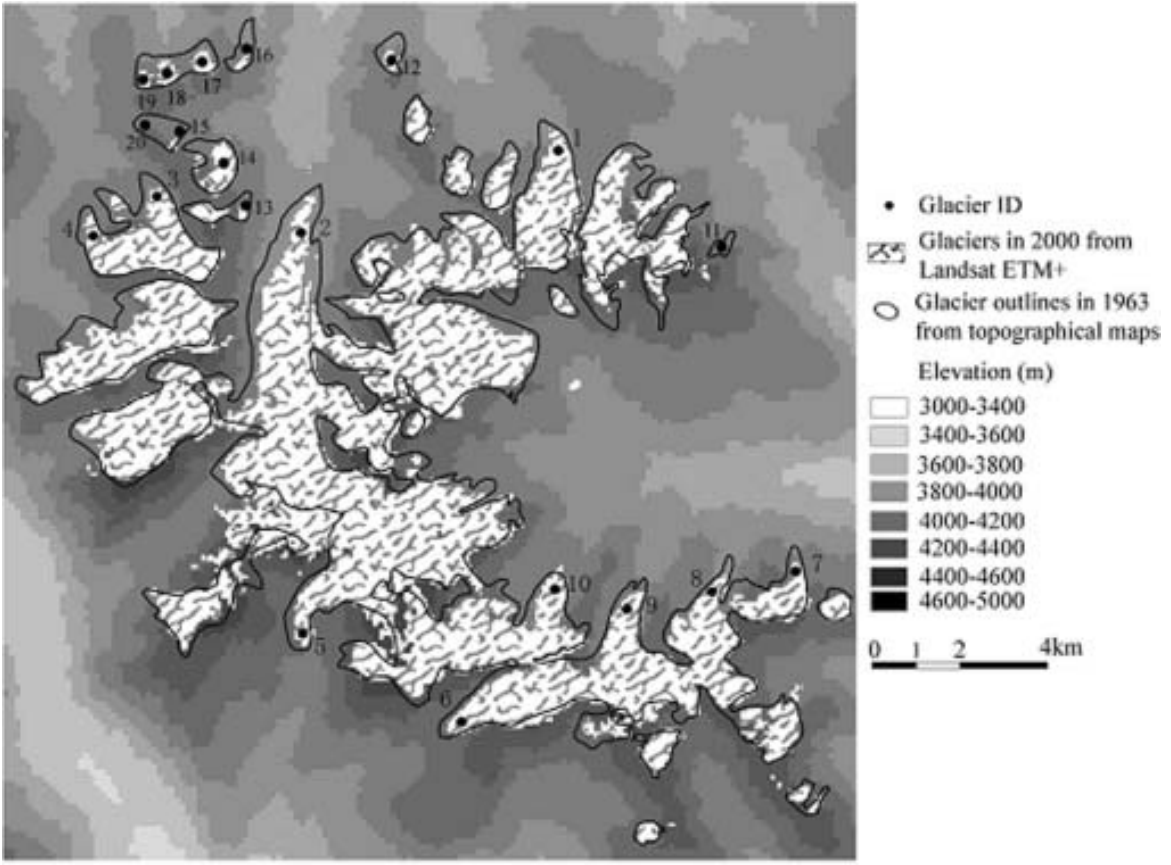

Fig. 6. Glacier area change and severely retreated glaciers between 1963 and 2000.

glaciers 11, 15 and 20 disappeared completely, and most parts of glacier 12, 13, 14, 16, 17, 18 and 19 melted substantially.

\section{INTERPRETATION AND DISCUSSION \\ Glacier fluctuation and climate change}

In the study area, glaciers mainly melt in summer, from June to August. The summer mean temperature from June to August is specified as the climate change index for studying the effect of climate change on mountain glaciers. In this study we obtained the summer mean temperature between 1963 and 2000 from Bayanblak meteorological station in the upper reaches of the Kaidu river, the closest meteorological station to the study area.

The temperature change was generally consistent with the glacier change over the past four decades. The mean temperature from June to August throughout the past four decades shows an increasing trend (Fig. 7), with slope $\sim 0.3^{\circ} \mathrm{C}_{\text {decade }}{ }^{-1}$. The temperature rose by $>1^{\circ} \mathrm{C}$ between 1963 and 1986.

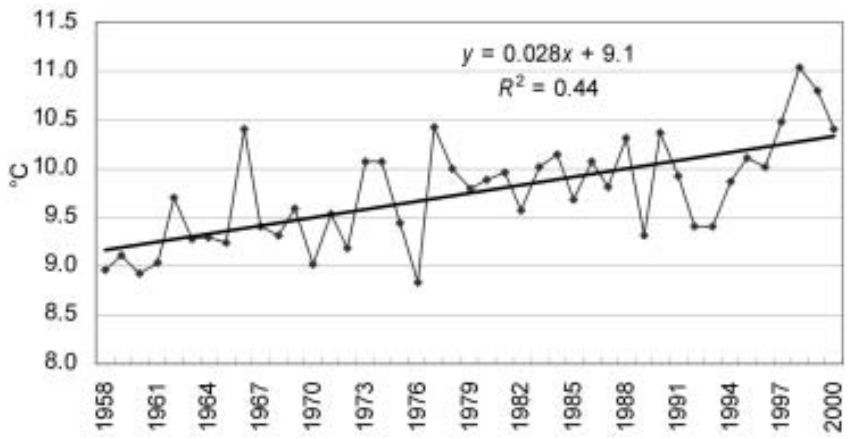

Fig. 7. The mean summer temperature at Bayanblak meteorological station between 1958 and 2000. The average temperature between 1958 and 2000 is $9.8^{\circ} \mathrm{C}$. (For the slope calculation $x=$ year -1958 .)

\section{Glacier fluctuation and runoff change}

The annual runoff was used as the runoff index to study the relationship between glacier change and runoff change. The annual runoff data are from the Dashankou hydrological gauge. The Dashankou gauge is located in the middle reaches of the Kaidu river, which is fed by glacial runoff from the study area. It is the only hydrological gauge in the upper and middle reaches of the Kaidu river where runoff has been measured continuously since the 1960s.

Generally, the runoff change and the precipitation change were consistent between 1958 and 1994, but they have not been in agreement during the last decade (Fig. 8). Runoff for the 7 years 1994-2000 was generally above the average over the period 1958-2000 and was over 15\% more than the average in five of the seven years. However, for four of the seven years, precipitation was less than average. This shows that there has been an unexplained discrepancy between precipitation and runoff over the past decade.

A Fourier transform was applied to the time series of runoff and precipitation to reveal temporal recurring patterns greater than 4 years (with a frequency less than 0.25) (Fig. 9). The aforementioned discrepancy is confirmed through this analysis. Prior to 1995, fluctuations in precipitation and runoff were in agreement, but after 1995, precipitation decreases and runoff increases. We believe this discrepancy is related to increased glacier melt over the past decade.

\section{Comparison with measurements in the Ürümqi river basin}

Glacier changes in the study area and in the Ürümqi river basin have been similar over the period of interest. UG1, in the Ürümqi river basin, has retreated continuously since the 1960s at $\sim 4.5 \mathrm{~m} \mathrm{a}^{-1}$ between 1962 and 1993, for a total of $139.7 \mathrm{~m}$. In 1993, UG1 divided into two streams: the east stream with a recession rate of $3.7 \mathrm{~m} \mathrm{a}^{-1}$ and the west stream with a recession rate of $5.7 \mathrm{~m} \mathrm{a}^{-1}$ between 1993 and 2001 . The area of UG1 decreased by $11.0 \%$ between 1962 and 2000 (Li and others, 2003). 


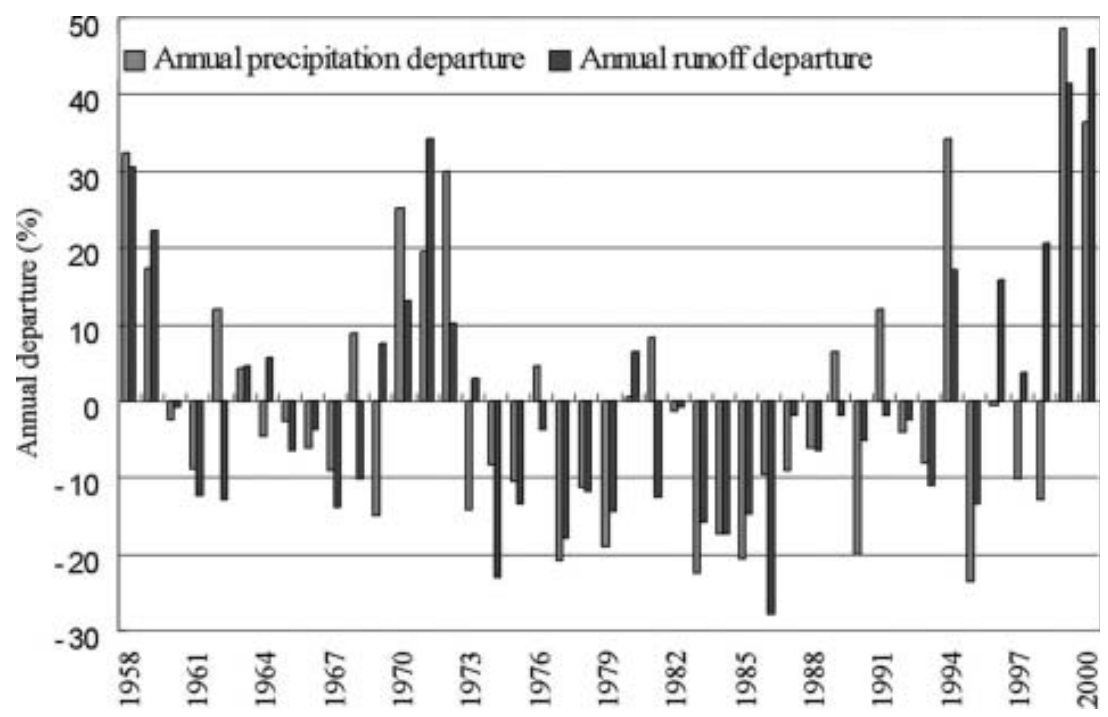

Fig. 8. Time series of annual precipitation departure and annual runoff departure (percent above or below the long-term mean) at Bayanblak meteorological station and Dashankou hydrological gauge between 1958 and 2000. The average annual runoff between 1958 and 2000 was $10.8 \times 10^{9} \mathrm{~m}^{3}$; the average precipitation between 1958 and 2000 was $273.4 \mathrm{~mm}$.

\section{CONCLUSIONS}

Glaciers retreated continuously over the past 37 years in the study area. Nine out of the ten glaciers studied retreated, and seven of them retreated by at least $150 \pm 49 \mathrm{~m}$ between 1963 and 2000. The average recession rate of all glaciers studied, except for glaciers 5, 6 and 10, is $4-8 \mathrm{~m} \mathrm{a}^{-1}$. The recession rate between 1986 and 2000 was larger than between 1963 and 1986. The recession rate between 1963 and 1986 was $4-7 \mathrm{~m} \mathrm{a}^{-1}$ and between 1986 and 2000 was $5-12 \mathrm{~m} \mathrm{a}^{-1}$ for most glaciers. Between 1963 and 2000, the glacier area decreased from $55 \times 10^{6} \mathrm{~m}^{2}$ to $48 \times 10^{6} \mathrm{~m}^{2}$ (a $13 \%$ decrease). The changes were similar to those of UG1.

The glacier change has been consistent with temperature change and runoff variation. The summer mean temperature during the past 37 years rose continuously, possibly a direct cause of glacier recession over the same period. In the past decade, precipitation has decreased. Runoff has increased, possibly as a result of increased glacier melt. The trend of runoff change plays an important role in the supply of water resources for the oases of the Chinese Tien Shan. It is important to clarify to what extent the runoff change has been caused by glacial melting, and the role of land use in runoff change. A hydrological modeling approach may be an effective method to solve these problems.

\section{ACKNOWLEDGEMENTS}

This study is supported by 973 Program (2006CB701305), China National Natural Science Foundation (40101028), and by the 'One-Hundred Talents Program' of the Chinese Academy of Sciences. Constructive criticism and comments by R. Naruse (Scientific Editor), D. Hall and an anonymous referee are acknowledged.

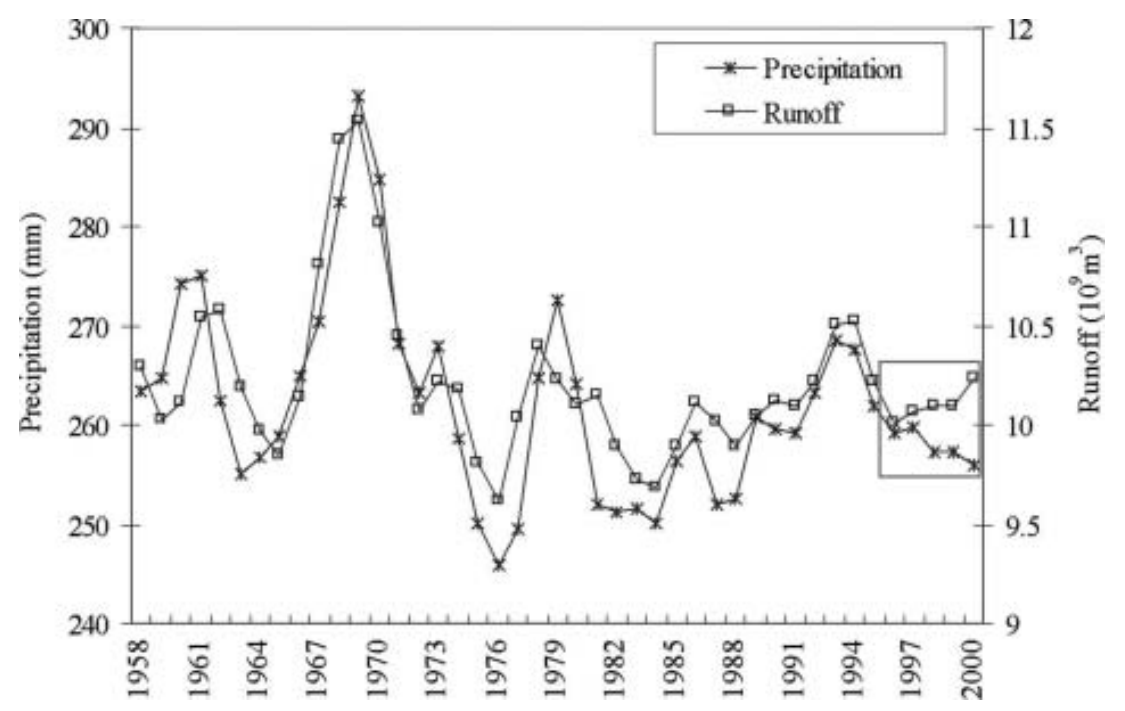

Fig. 9. Time series of annual precipitation and annual runoff. The patterns within 4 years based on the Fourier transform were removed. The increase and decrease of precipitation and runoff agreed before 1995, but the precipitation decreased and the runoff increased after 1995. 


\section{REFERENCES}

Cao, M.S. 1998. Detection of abrupt changes in glacier mass balance in the Tien Shan Mountains. J. Glaciol., 44(147), 352-358.

Congalton, R.G. and K. Green. 1999. Assessing the accuracy of remotely sensed data: principles and practice. Boca Raton, FL, Lewis Publishers.

Fujita, K., Y. Ageta, J. Pu and T. Yao. 2000. Mass balance of Xiao Dongkemadi glacier on the central Tibetan Plateau from 1989 to 1995. Ann. Glaciol., 31, 159-163.

Haeberli, W., M. Zemp, R. Frauenfelder, M. Hoelzle and A. Kääb, eds. 2005. Fluctuations of glaciers 1995-2000 (Vol. VIII). Zürich, World Glacier Monitoring Service.

Hall, D.K., K.J. Bayr, W. Schöner, R.A. Bindschadler and J.Y.L. Chien. 2003. Consideration of the errors inherent in mapping historical glacier positions in Austria from ground and space (1893-2001). Remote Sens. Environ., 86(44), 566-577.

Jin, R., L. Xin, T. Che, L. Wu and P. Mool. 2005. Glacier area changes in the Pumqu river basin, Tibetan Plateau, between the 1970s and 2001. J. Glaciol., 51(175), 607-610.

Kjøllmoen, B., ed. 2006. Glaciological investigations in Norway in 2004. NVE Rapp. 2.

Lanzhou Institute of Glaciology and Geocryology (LIGG). 1987. Glacier inventory of China. Vol. III. Tien Shan, Southwest of Tarim River Inner Basin. Beijing, China Science Press. Academia Sinica, Lanzhou Institute of Glaciology and Geocryology. [In Chinese.]
Li, Z., T. Han, Z. Jing, H. Yang and K. Jiao. 2003. A summary of 40year observed variation facts of climate and Glacier No. 1 at headwater of Ürümqi River, Tien Shan, China. J. Glaciol. Geocryol., 25(2), 117-121. [In Chinese.]

Liu, S., W. Sun, Y. Shen and G. Li. 2003. Glacier changes since the Little Ice Age maximum in the western Qilian Shan, northwest China, and consequences of glacier runoff for water supply. J. Glaciol., 49(164), 117-124.

Paul, F. 2002. Changes in glacier area in Tyrol, Austria, between 1969 and 1992 derived from Landsat TM and Austrian glacier inventory data. Int. J. Remote Sensing, 23(4), 787-799.

Shi, Y., M. Huang, T. Yao and Y.X. Deng. 2000. Glaciers and their environments in China - the present, past and future. Beijing, Science Press. [In Chinese.]

Sidjak, R.W. and R.D. Wheate. 1999. Glacier mapping of the Illecillewaet icefield, British Columbia, Canada, using Landsat TM and digital elevation data. Int. J. Remote Sensing, 20(2), 273-284.

Silverio, W. and J.M. Jaquet. 2005. Glacial cover mapping (19871996) of the Cordillera Blanca (Peru) using satellite imagery. Remote Sens. Environ., 95(3), 342-350.

Wang, N., K. Jiao, Z. Li, Z. Jing and T. Han. 2004. Correspondence. Recent accelerated shrinkage of Ürümqi glacier No. 1, Tien Shan, China. J. Glaciol., 50(170), 464-466.

Yang, J., Y. Ding, R. Chen, S. Liu and A. Lu. 2003. Causes of glacier change in the source regions of the Yangtze and Yellow rivers on the Tibetan Plateau. J. Glaciol., 49(167), 539-546.

MS received 19 February 2006 and accepted in revised form 15 June 2006 